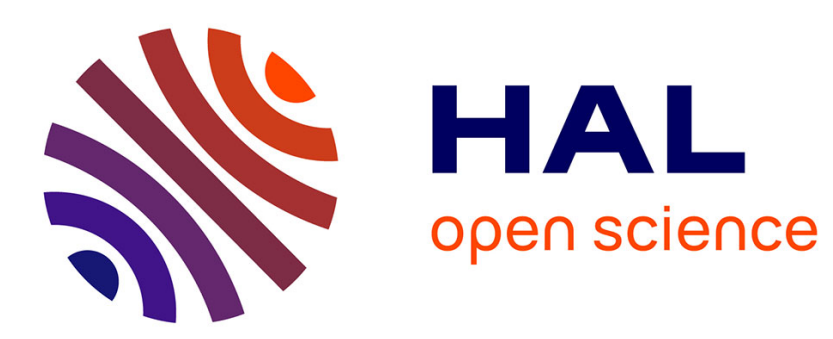

\title{
ROSCAs in Urban Ethiopia: Are the characteristics of the institutions more important than that of members?
}

\author{
Abbi Kedir, Gamal Ibrahim
}

\section{To cite this version:}

Abbi Kedir, Gamal Ibrahim. ROSCAs in Urban Ethiopia: Are the characteristics of the institutions more important than that of members?. The Journal of Development Studies, 2011, 47 (07), pp.9981016. 10.1080/00220388.2010.536219 . hal-00720856

\section{HAL Id: hal-00720856 https://hal.science/hal-00720856}

Submitted on 26 Jul 2012

HAL is a multi-disciplinary open access archive for the deposit and dissemination of scientific research documents, whether they are published or not. The documents may come from teaching and research institutions in France or abroad, or from public or private research centers.
L'archive ouverte pluridisciplinaire HAL, est destinée au dépôt et à la diffusion de documents scientifiques de niveau recherche, publiés ou non, émanant des établissements d'enseignement et de recherche français ou étrangers, des laboratoires publics ou privés. 


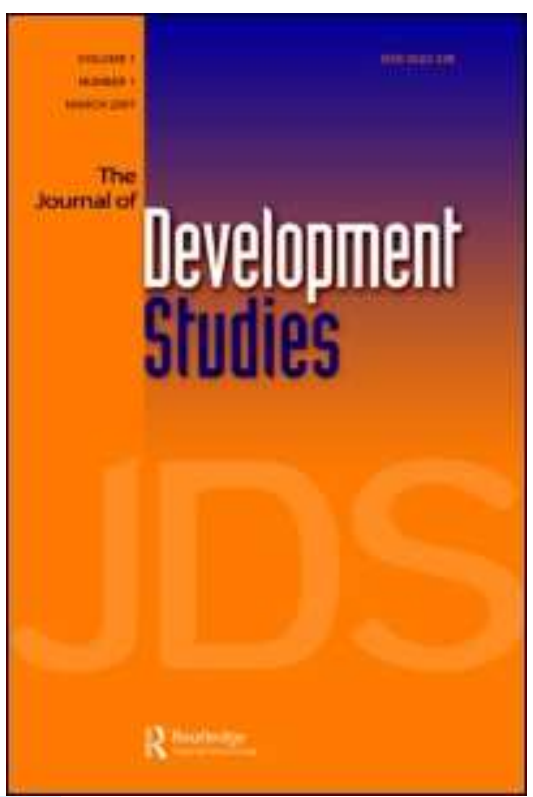

ROSCAs in Urban Ethiopia: Are the characteristics of the institutions more important than that of members?

\begin{tabular}{|r|l|}
\hline Journal: & Journal of Development Studies \\
\hline Manuscript ID: & FJDS-2009-Aug-0011.R3 \\
\hline Manuscript Type: & Original Manuscripts \\
\hline Keywords: & $\begin{array}{l}\text { Africa < Geographical Area, Economic development < Economics, } \\
\text { East Africa < Geographical Area }\end{array}$ \\
\hline
\end{tabular}

\section{SCHOLARONE ${ }^{\text {tw }}$ \\ Manuscripts}


ROSCAs in Urban Ethiopia: Are the characteristics of the institutions more important than that of members?

\begin{abstract}
Using household data from urban Ethiopia, we provide an empirical test of the economic theory of Rotating Savings and Credit Associations (ROSCAs) and identify the impact of ROSCAs and member characteristics on participation and volume of saving. Unlike other studies, we account for the endogeneity of all ROSCA variables. Muslims, individuals who live in richer households, the self-employed, private sector employees and households with large numbers of women are more likely to join ROSCAs. A robust finding is that the savings are significantly affected by the characteristics of the members but not that of the informal saving institution. Some policy implications are discussed.
\end{abstract}

\title{
I. INTRODUCTION
}

Informal financial institutions such as Rotating Savings and Credit Associations (ROSCAs) and their participants have received growing attention over the last two decades. A recent study on urban Ethiopia provided detailed evidence of the important role of informal finance in consumption smoothing of households (Alvi and Dendir, 2009). A particular emphasis on studying ROSCAs has been placed on their role in resource mobilisation. Informal finance, once the preserve of anthropologists and sociologists, is capturing the attention of economists. The findings from field research in several developing countries suggest that the role of informal finance in resource 
mobilisation and allocation is quantitatively significant, even if at most only 20 percent of African households have access to formal finance (Honohan and Beck, 2007).

As formal credit markets are missing or not competitive if present, government intervention to address imperfections and failures in the formal credit market can be justified (Besley, 1994). However, subsidised government interventions often failed, mainly due to implementation inefficiency and informational uncertainty, leading to a re-evaluation of the role of informal finance (Callier, 1990, UNCTAD, 2007). Addressing problems associated with informational asymmetries, moral hazard and adverse selection for the design of specific policies and institutions motivated research on informal financial markets (Diagne and Zeller, 2001; van den Brink and Chavas, 1997; World Bank, 2008).

The contribution of this paper stems from the scarcity of econometric evidence on the workings of ROSCAs in urban Sub-Saharan Africa, as the literature has focussed on rural households. We know very little about informal institutions used by urban households (Cox and Jimenez, 1998; Alvi and Dendir, 2009). The study attempts to encourage debate on whether empirical support for the Besley, Coate and Loury (1993) theory is robust. ROSCAs provide valuable service to those excluded from access to capital, public assistance and insurance programmes. This is mainly achieved via ingenuous saving mobilisation among neighbours, friends and relatives not only in urban Ethiopia and other African countries but also right across the developing world. ROSCAs and other forms of traditional institutions are significant devices for the poor in their attempts to diffuse the impact of shocks (Hoddinott, Dercon and Krishnan, 2005) as well as building trust and social capital (Etang, Fielding and Knowles, 2007). 
Therefore, it is informative to analyse what determines households' ROSCA participation and the amount of saving mobilised via such an institution. The research points to the importance of local level resource mobilisation and the need to support such initiatives to build a better financial infrastructure in these economies.

There are very few studies on Ethiopian ROSCAs (equbs) particularly in urban areas. The very limited literature that exists is both very descriptive and rather outdated (Aredo, 1993; Begashaw, 1978). It is therefore useful to provide an empirical analysis on how these institutions work in Ethiopia and what determines members' participation and the amount they save. This paper contributes to the current scanty literature on urban ROSCAs in developing countries by identifying the factors that significantly affect participation decision as well as the amount of ROSCA saving/contribution, controlling for the size of ROSCA and the frequency of saving/contribution. Unlike Handa and Kirton (1999) for Jamaica, we found these two variables to be insignificant and caution against accepting the findings of Besley et al (1993) in relation to these two variables as a stylised/robust fact which is applicable everywhere. However, this does not mean that the two variables are not important in our understanding of other aspects of ROSCAs. Handa and Kirton (1999) showed their crucial role in predicting the probability of a problem occurring within a ROSCA group.

A standard probit as well as a selection equation set of parameters were estimated to identify the factors that significantly predict the probability of participation in ROSCAs. The determinants of the amount of ROSCA savings are identified using different but relevant estimators, Ordinary Least Squares (OLS), instrumental variables 
(IV), the primary (conditional) equation of the Heckman Two-Step estimator and the tobit estimator. More detailed discussion of results and their policy implications are provided in the results section of the paper.

The remainder of this paper is structured as follows. Section 2 gives a brief background of ROSCAs in Ethiopia. Section 3 summarises the relevant literature. Section 4 provides an outline of the relevant parts of the theoretical model developed by Besley et al (1993) and highlights its testable proposition in the context of our study. Section 5 discusses the data used in this study and provides some descriptive statistics about equb and members in Ethiopia. Section 6 outlines the statistical methods adopted in the analysis. Section 7 discusses the empirical results while Section 8 considers policy implications and concluding remarks.

\section{BACKGROUND ON ETHIOPIAN ROSCA}

In Ethiopia, ROSCAs are widespread both in urban and rural areas. In some cases, these institutions have homogeneous membership. For instance, there are ROSCAs formed only by women, traders, employees of a given organisation and by individuals of similar ethnic or religious group. In other instances, ROSCAs have heterogeneous membership consisting of males and females that come from all walks of life including children whose contributions are often made by parents. In cases where a child works, the child handles the saving commitment obligations. Often geographical proximity (i.e. same neighbourhood) is the prime consideration when forming these interesting saving institutions. In addition to serving as saving vehicles, these institutions create the opportunity for members in a given location to meet and discuss non-financial 
issues (e.g. to settle social and personal problems). ROSCAs can be big as well as small depending on the socio-economic conditions of participants and the purpose of saving. They serve as important vehicles of mutual assistance in times of need and emergencies.

ROSCAs have an important role to play in terms of resource mobilisation. The sum mobilised by ROSCAs is not negligible. The estimates reported by Bouman (1995) indicate that the saving mobilised by equbs (the local name for Ethiopian ROSCAs) is equivalent to 8 to 10 percent of GDP in Ethiopia. In our current sample, the reported saving mobilised is $1,147,948$ Ethiopian birr as the total reported by 377 ROSCA members. This is equivalent to saving of $£ 266$ per household (3045 Ethiopian birr) which is a substantial amount of money by Ethiopian standards. However, the relevance of ROSCA as a consumption or investment finance vehicle should not be overstated. A closer look at recent Ethiopian household surveys shows that despite the high level of household credit constraints, informal institutions such as ROSCAs and money lenders have not emerged as significant sources of credit. The most predominant source of loans remains 'family and friends' (Kedir, Ibrahim and Torres, 2010).

Using household level data from urban Ethiopia, we provide an empirical test of the ROSCA theory developed in the seminal contribution of Besley et al (1993). We test whether the size of ROSCA contribution is negatively related to the size of ROSCA in the Ethiopian context by estimating an equation for monthly contribution controlling for potential endogeneity of ROSCA characteristics. We use a discrete model to provide quantitative evidence on the determinants of ROSCA participation. Gugerty 
(2007) argues that ROSCAs provide a collective mechanism to discipline their members to save in the presence of time-inconsistent preferences. In our setting, this argument can be tested by investigating the relationship between household income and ROSCA participation. As motives to save are increasing in income, following Levenson and Besley (1996), one would expect ROSCA participation and ROSCA contributions to increase with household income. As noted earlier, very few econometric tests corroborate or challenge these theoretical postulates on ROSCAs especially using data from Sub-Saharan Africa (Anderson and Baland, 2002). Our data provide a unique opportunity to undertake this task as it contains individual, household and ROSCA level characteristics. It also provides information on participants and nonparticipants of formal and informal financial institutions. Our test is conducted in an urban setting where the formal sector is expected to be dominant. To give context and more depth to our analysis and to interpret results appropriately, we describe the characteristics of urban households that saved in informal institutions in comparison to those that did not.

\section{Literature}

Due to the weakness of existing formal saving schemes and prevalence of traditional support mechanisms in developing countries, ROSCAs are one of the most important informal financial institutions. These partnerships are formed by a group of participants who make regular contributions to a fund, which is given to each contributor in turn until each member receives the fund once. The allocation procedure of the ROSCA determines the net benefit that each member derives and could thus be an important factor in the success of ROSCAs. Usually, the ROSCA leader (a ROSCA 
judge in the Ethiopian context) or 'banker' decides on the order of recipients, often based on a random drawing rule. In practice, the ROSCA judge can consider the immediate financial need of some members and let them take the ROSCA pot in earlier rounds. For instance, a member might want the money for urgent medical conditions and other emergencies. A random ROSCA (the common form in Ethiopia) allocates its pool of funds based on random drawing of lots, with the winning member receiving the pool. This process is repeated with each previous recipient of the pool being excluded from the draw until each participant has received the pool once. A bidding ROSCA (common in Asia) is one where participants bid competitively for the pool which is allocated to the highest bidder. As in other ROSCAs, participants receive the pool only once over the life cycle of the specific ROSCA. In Ethiopia, it is common for more than one individual from a given household to belong to a ROSCA. In such a case, the participating household receives the pot more than once.

Low income countries have developed nonmarket institutions such as ROSCAs to cope with risk and to improve credit access. The fund collected from individual contributions by members is a useful risk sharing arrangement in case of idiosyncratic shocks. It can be used to purchase indivisible durable consumption goods and/or to smooth consumption. ROSCAs bring borrowers and savers together, with early recipients of the fund being borrowers and the late ones acting as savers/lenders. Savings through ROSCAs can be thought of as gains from trade that arise in intertemporal contracting between individuals. ROSCAs are common not only in LDCs but also in newly industrialised countries such as Taiwan and in developed countries such as the United states, and are mainly formed by immigrant communities which are more likely to be cut off from the formal saving outlets such as banks (Handa and Kirton, 
1999; Ibrahim and Galt, 2003; Levenson and Besley, 1996; Besley, 1995; Srinivasan, 1995; Bonnet, 1981; Besley et al. 1993).

There is a continuous controversy in the literature over the motives of ROSCA membership and there is still no consensus. The literature provides various reasons why individuals/households join ROSCAs. The motives include, amongst others, the need to acquire consumer durables (Hinda and Kirton, 1999; van den Brink and Chavas, 1997; Besley and Levenson, 1996; Levenson and Besley, 1996; Besley et al 1993); intra-household conflict in resource allocation (Anderson and Baland, 2002; Ardener and Burman, 1995); insurance (Klonner, 2003; Calomiris and Rajaraman, 1998); commitment issues (Dagnelie and LeMay-Boucher, 2009); self-control over the use of funds in the presence of time inconsistent preferences (Gugerty, 2007) and handling social pressure (Ambec and Treich, 2007). In practice, we observe multiple reasons.

\section{Theory}

We follow the Besley et al (1993) two-good model based on random ROSCA. The model compares the lifetime utilities of individuals with and without ROSCA membership. The model makes the following assumptions. A group of $n$ individuals would like to own an indivisible durable good. The individuals have no access to credit markets. Each individual lives for $T$ years, receiving an exogenous flow of income over a lifetime of $y>0$. Individuals have identical, inter-temporally additive preferences. The services of the durable good are not fungible across individuals. In other words, the good yields a constant flow of services and an individual must own it 
to benefit from its services. Households in Ethiopia often save to buy durables such as fridges, household furniture, machinery and cars (mainly taxies and other commercial vehicles for self employment).

If $v(1, c)$ is the utility from non-durable consumption, $c$, if the durable is owned and $v(0, c)$ is the same utility if the durable is not owned, $\delta v(c)=v(1, c)-v(0, c)$. Given $\theta$ as the probability of owning the good, the expected utility is

$$
v(\theta, c)=\theta v(1, c)+(1-\theta) v(0, c)
$$

The model results are validated by imposing the conditions that $\delta v(c)>0$ and $\delta v^{\prime}(c) \geq 0$. These conditions are assumptions about the structure of preferences. The first condition states that the durable is liked by the individuals and the second assumes that the marginal utility of non-durable consumption is not decreasing by owning the indivisible good suggesting complimentarity between durable services and non-durable consumption. The theoretical literature argues that agents gain from inter-temporal trade by joining a ROSCA. This implies that the lifetime utility of the individual who decides to save alone (that is autarky) is lower relative to the individual who joins a (random) ROSCA. The following shows the comparison of lifetime utilities from saving with and without ROSCA membership. To indicate the link between the theory and our empirical testing, we discuss the key testable proposition coming out of the theory from equation (2) below.

\section{Utility from Autarkic Saving}

An individual may save $B$ at a constant rate $(y-c)$ over an interval $[0, t]$. Under autarky, the individual maximises his/her lifetime utility by choosing $t$ and $c$. 


$$
\begin{aligned}
& \underset{t, c}{\operatorname{Max}}\{(T-t)*[v(1, y)]+t *[v(0, c)]\} \\
& \text { s.t. } \quad t^{*}[y-c]=B \text { and } 0 \leq c \leq y
\end{aligned}
$$

where;

$y=$ income of the individual.

$T-t=$ a period or the years the individual lives without saving to buy the durable good.

$B=$ total saving up to point $\mathrm{t}$ or cost of the indivisible

$(y-c)=$ contribution/saving each time

The first term of (2) represents the utility if the individual owns the durable and the second term refers to lifetime utility if the individual does not own the durable. Under autarky, no individual has the durable good before $t$ at which time all $n$ individuals have it. Each person saves at the rate $(y-c)=B / t$ and after an interval $t / n$, there are enough savings to buy an indivisible good. This makes autarky inefficient because the individual will have to wait until $t$ to have enough saving to buy the durable good. Saving through random ROSCA avoids the inefficiency as explained below.

\section{Utility from Saving through Random ROSCA}

Suppose there is a random ROSCA (the most common Ethiopian variety) formed by $n$ members and they meet at equally spaced dates up to $t$ (that is $t / n, 2 t / n, \ldots, t$ ) with contributions at each meeting. For instance, if there are 12 equb members who decide to meet monthly, they will meet 12 times according to the simple rule $12 / 12,2(12) / 12$, $\ldots .12(12) / 12$ or $1,2, \ldots 12$. Individuals save at rate $B / t$ and expect to receive the durable $t[(n-1) / 2 n]$ sooner. Clearly, all members of a random ROSCA are better off 
One of the most important theoretical predictions expressed in the constraint of equation (2) is the inverse relationship between the amount of contribution per unit of time (that is $y-c$ ) and the size of ROSCA $(n)$. We know that $t^{*}(y-c)=B$ or $y-c=B / t$ or $B / n$. In the words 'the duration of the ROSCA will be inversely proportional to the rate at which the group saves' (Besley et al, 1993, p. 796). Alternatively, the larger the size of the individual contribution per member, the smaller will be the number of ROSCA members and the shorter the ROSCA duration. Then the interesting question will be: are the characteristics of ROSCA (i.e. size and frequency of saving) more important than the characteristics of savers and the households they live in (i.e. household income, age and other socio-economic characteristics)? This is fundamental for policy and enables us to put the theory to more scrutiny.

\section{Data and Descriptive Statistics}

The data used in this study were collected in 1994 from seven urban centres in Ethiopia by the Department of Economics of Addis Ababa University in collaboration with the Department of Economics of University of Gothenburg. The cities covered in the survey include Addis Ababa (i.e. the capital city), Awassa, Bahar Dar, Dessie, Diredawa, Jimma and Mekele. A total of 1500 households were interviewed to provide information on household demographics, income, expenditure, education, assets, 
health and individual/household participation in formal and informal financial institutions. The sample of households surveyed is intended to be representative of the main socio-economic characteristics of the cities. The total sample was distributed over the selected urban centres proportional to their populations, based on the Central Statistical Authority (CSA) 1992 population projections. Thus, 900 households were drawn from Addis Ababa, 126 from Dire Dawa, 73 from Awassa, 101 from Dessie and 100 from each of the remaining three cities (Gebremedhin and Whelan, 2008). Proportional samples were then taken from all weredas (districts) in each of the urban centres and half of the kebeles (the lowest administrative units) selected randomly from each wereda. Finally, using the registration of residential houses at the kebele administrative offices as the sampling frame, systematic sampling was used to select households from each of the kebeles.

Relevant information was obtained by asking whether any member of the household is a member of equb, the frequency of saving, the amount of equb contribution per month, the amount paid out by the equb and the amount expected to be received from the equb. The definition of dependent variable for the discrete choice model is based on the question "is any member of the household a member of an equb?" Based on responses, the dependent variable takes a value of 1 if any member of the household participated and 0 otherwise. Two crucial variables are the amount paid out by the $e q u b$ and the amount expected to be received from the $e q u b$, which are added together to get the total ROSCA fund obtained by a ROSCA participant. To define the ROSCA size, we divided this sum by the contribution. 
Using the demographic file, we defined the characteristics of the household head such as gender, age, level of schooling, labour market status, ethnic origin and religious affiliation. Due to the rich array of information at our disposal we were also able to define equb specific characteristics such as the frequency of draw and size of equb. From other sections of the data we defined household characteristics and welfare indicators such as total household expenditure (preferred indicator of the permanent income position of households), household size, demographic composition and location.

The data sheds light on some of the controversial questions in the literature, such as why do households save through equb? Table 1 lists, in order of importance, the purpose of membership in equbs as reported by the participants. Consistent with the lumpy durable purchase argument advanced by Besley et al (1993), over 45 percent of our respondents save to buy consumer durables, by far the most important reason why individuals in urban Ethiopia join equb. About one-fifth $(20 \%)$ of the individuals joined $e q u b$ to save without mentioning the reason why the saving is being made. This can probably be thought of as precautionary saving which can be put to use in times of crisis. A non-negligible proportion of respondents join equb to raise the funds for investment reasons (about 17.4\%) and just under 10 per cent of them save for altruistic reasons either to support some of their family members and/or friends. Our evidence is also in agreement with Gugerty (2007) and Ambec and Treich (2007), which provide evidence on both durable good and social pressure motivations for joining ROSCA. The purchase of durable goods could be considered as an effective tool for people willing to avoid social pressure as the durable goods cannot be divided among relatives (i.e. non-fungible). Although we could not empirically test that individuals who have 
hyperbolic preferences are more likely to join $e q u b$, we conjecture that people prefer not to make petty expenditures. They rather save and allocate the saving for indivisible expenditure items. This may be attributed to a number of reasons, such as dealing with self control problems, protection of savings against social pressure and risk of theft. So, by joining equb, people might use the membership as an opportunity to opt for a socially acceptable means of protecting their savings against various types of social pressures (Platteau, 2000).

Table 1: Purpose of Equb Membership

\begin{tabular}{lc}
\hline \multicolumn{1}{c}{ Purpose } & Number of ROSCA members \\
& $(\boldsymbol{\%})$ \\
\hline To buy consumer durables & $176(45.2)$ \\
To save & $81(20.8)$ \\
To start/ expand business & $68(17.4)$ \\
To help friends and solve family problem & $32(8.1)$ \\
Other (rent, education expenses, building a house) & $28(7.1)$ \\
To buy food & $10(2.5)$ \\
To repay debts/to pay water and electricity bills & $7(1.7)$ \\
\hline All & $\mathbf{3 8 9}(\mathbf{1 0 0})$ \\
\hline
\end{tabular}

Who is more likely to be a member of equb? As expected, household heads or their partners are the ones who usually join equbs. However, children and other household members made savings through equbs but their number is insignificant in our sample. Hence, they are excluded from the analysis. 
Table 2 provides the background information on the equbs that our respondents joined. The size of equbs is modest, 24 being the median number of members and the duration of equbs is on average one year. However, over 25 percent of the equbs last longer than 52 weeks with 10 of them running for over 100 weeks. This is a similar length of time as found in Kenyan slums by Anderson and Baland (2002). The most common forms of equb meetings are the ones taking place monthly (in over 50\% of cases) and weekly (in about $38 \%$ of cases). The median $e q u b$ amount saved by households is 50 Ethiopian birr. This figure is different from the mean reported earlier due to large variation in savings across households.

\section{Table 2: Basic information on equbs}

\begin{tabular}{lc}
\hline \multicolumn{1}{c}{ Variable } & All equbs \\
\hline Median Number of members (St.Dev) & $24(15.9)$ \\
Median Weeks existed (St. Dev) & $52(52.5)$ \\
Contribute Daily (\% of equbs) & 2.8 \\
Contribute weekly (\%) & 37.7 \\
Contribute fortnightly (\%) & 6.1 \\
Contribute monthly (\%) & 49.6 \\
Median Monthly contribution in Birr? (St. Dev) & $50(52.2)$ \\
\hline No of observations & 377 \\
\hline
\end{tabular}

Note: St. Dev. denotes standard deviation. 
Table 3: Characteristics of Equb and non-Equb participants

\begin{tabular}{lll}
\hline Variable & Members & Non- members \\
\hline \multicolumn{1}{c}{ Mean characteristics } & $179.9(207.22)$ & \\
Total monthly contribution (mean) & $23.9^{* *}(12.6)$ & $27.8 * *(13.5)$ \\
Age & $891.0^{* *}(571.6)$ & $742.7^{* *}(706.3)$ \\
Household total expenditure & $6.7 * *(2.8)$ & $5.9 * *(2.8)$ \\
Household size & $2.1(1.8)$ & $1.9(1.7)$ \\
Number of children & & 53.6 \\
& 68.2 & 33.1 \\
Females & 12.2 & 23.4 \\
Illiterate & 33.0 & 35.0 \\
Primary schooling & 35.1 & $\mathbf{1 0 3 7}$ \\
Secondary schooling & 7.5 & \\
Tertiary schooling & $\mathbf{3 7 7}$ & \\
\hline Number of observations & & \\
\hline Notes:** indicates means are statistically different at $5 \%$ level of significance. & \\
\hline
\end{tabular}

Notes: ** indicates means are statistically different at $5 \%$ level of significance.

Table 3 provides a comparison of the characteristics of the individual who participated in equbs and those who did not. According to the results, equb members are more likely to be females, come from richer households and live in larger households. The fact that a large number of richer households tend to join equb might indicate their low confidence in the formal financial sector in urban Ethiopia (although it is common for such households to save both in banks and ROSCAs). Even if they have a choice of making saving only in banks, they can save in ROSCAs both for financial and nonfinancial reasons. Another interesting finding is the high proportion of illiterate 


\section{Econometric framework}

We are interested in identifying the significant household and individual level characteristics that affect participation in $e q u b$ and the level of equb contribution and test the importance of ROSCA related variables in comparison to variables defined for savers. The probability of joining equb is modelled using a probit model. This is because the dependent variable is a binary/discrete outcome which takes a value of 1 if any member of the household belongs to equb and 0 otherwise. To account for potential non-random nature of participation, we estimated this probability from a selection equation which is given as a $1^{\text {st }}$ stage regression of the Heckman two-step procedure (Heckit). The standard probit and the selection equations are reduced-form equations showing the relationship between micro-level variables such as household and household head characteristics and equb participation (i.e. the outcome of interest). The key individual variables are age, gender, ethnic origin, religion, years of schooling completed and employment status. It is appropriate to define these variables for the household head as he/she is often the economic head of any given household in Ethiopia. In addition, almost all of the equb members are heads of a given household. As a breadwinner, the head is responsible for making crucial resource allocation 
decisions including savings in equbs. In addition to the characteristics of the head, general household level variables such as total expenditure and household demographic composition were incorporated in the estimations.

The second key estimating equation is the equb contribution equation. To investigate the determinants of equb contribution in a robust manner, we used three specifications, namely Ordinary Least Squares (OLS), instrumental variable (IV) two stage least squares (2SLS) and Heckit estimators. The OLS estimates do not control for endogeneity of equb characteristics such as 'frequency of equb draw' and the 'size of $e q u b$ ' while the IV estimates address this potential problem. The Heckit procedure controls for the potential selectivity bias in the primary equb contribution equation by including the Inverse Mills Ratio (IMR) estimated from the $1^{\text {st }}$ stage selection equation. In the results section, we present and discuss the estimates of the three estimators. Unlike other applications (for example, Handa and Kirton, 1999 for Jamaica), we instrumented not only the 'frequency of draw' variable but also the 'size of $e q u b^{\prime}$. Both variables are potentially endogenous because they can be chosen by members.

\section{Results}

\section{a. Determinants of equb participation}

Table 4 reports the probit and selection model results and we focus discussion only on significant and interesting results. For comparison and checking the robustness of estimated parameters, standard probit (column 2) and selection equation (column 3) estimates are given. Except for the religion dummy (Muslim) and the ethnic group variable (Gurage), there is no major change in terms of sign or significance of 
Table 4: Probability of Equb participation

\begin{tabular}{lll}
\hline Variable & $\begin{array}{l}\text { Probit } \\
\text { Coefficients } \\
\text { (s.e.) }\end{array}$ & $\begin{array}{l}\text { Selection } \\
\text { Equation } \\
\text { Coefficients(s.e) }\end{array}$ \\
\hline Constant & $-1.08(5.72)$ & $-2.42(5.71)$
\end{tabular}

Household head characteristics 


\begin{tabular}{|c|c|c|}
\hline $\operatorname{Ln}($ Age $)$ & $-0.68(2.99)$ & $0.06(2.98)$ \\
\hline Ln(age) squared & $0.05(0.39)$ & $-0.05(0.40)$ \\
\hline Female & $0.004(0.09)$ & $0.02(0.09)$ \\
\hline \multicolumn{3}{|l|}{ Other religions (reference) } \\
\hline Orthodox & $0.04(0.17)$ & $0.012(0.15)$ \\
\hline Muslim & $-0.32(0.20)^{*}$ & $0.34(0.17)^{* *}$ \\
\hline Years of schooling & $0.01(0.007)$ & $0.004(0.007)$ \\
\hline \multicolumn{3}{|l|}{ Unemployed (reference) } \\
\hline Employer & $0.26(0.27)$ & $0.27(0.026)$ \\
\hline Self-employed & $0.52(0.11)^{* * *}$ & $0.59(0.11)^{* * *}$ \\
\hline Civil servant & $0.10(0.11)$ & $0.12(0.11)$ \\
\hline Private/International organisation & $0.41(0.17)^{* *}$ & $0.43(0.17)^{* *}$ \\
\hline Pensioner & $-0.02(0.13)$ & $-0.02(0.13)$ \\
\hline \multicolumn{3}{|l|}{ Other ethnic groups (reference) } \\
\hline Amhara & $0.19(0.15)$ & $0.02(0.12)$ \\
\hline Oromo & $0.13(0.16)$ & $-0.01(0.13)$ \\
\hline Tigre & $0.06(0.19)$ & $-0.07(0.15)$ \\
\hline Gurage & $0.37(0.17)^{* *}$ & $0.16(0.15)$ \\
\hline
\end{tabular}

\section{Household characteristics}

$\log ($ total expenditure)

$\log ($ total expenditure) squared

Number of Male Adults $\geq 15$ (excluded)

Number of Children $<15$

Number of Female Adults $\geq 15$

Log-likelihood

$$
\begin{array}{ll}
0.35(0.44) & 0.38(0.43) \\
-0.02(0.03) & -0.01(0.03)
\end{array}
$$

$$
0.01(0.02) \quad-0.003(0.02)
$$$$
0.08(0.02)^{* * *} \quad 0.07(0.02)^{* * *}
$$$$
\begin{array}{ll}
-782.86 & -1343.684
\end{array}
$$ 
LR Chi2( Prob>chi2) 84.17(0.0000)

Wald Chi2(Prob>chi2)

$210.9(0.0000)$

\section{No of observations}

1414

1414

Notes: Other estimated models include a probit model allowing for robust standard errors and also the heteroscedastic probit regression model (hetprob). The results did not lead to any qualitative changes in the estimated parameters of the model and their statistical significance.

\section{b. Determinants of size of equb contribution}

We provide econometric evidence to test the theoretical predictions advanced in the ROSCA literature in relation to the link between the amount of equb contribution and relevant regressors including equb characteristics (Handa and Kirton, 1999). The equb characteristics are captured by equb size and frequency of equb draw. Equb contribution is represented by the amount of Ethiopian birr paid into an equb fund by a given household during the month preceding the survey. Table 5 presents results of the OLS, IV/2SLS and Heckit regressions of equb contribution on individual, household and equb level characteristics in columns 2, 3 and 4 respectively. Our most important finding is that the amount of $e q u b$ saving is significantly affected by $e q u b$ member characteristics but not by equb characteristics in Ethiopia. This is robust for the three estimators adopted.

Age of the head is a significant determinant of $e q u b$ contribution and demonstrates a U-shaped quadratic relationship. But this relationship disappears once we account for endogeneity. However, with or without endogeneity correction, there is a robust inverted U-shaped relationship between household expenditure and contribution. This shows that households which are at the lower end of the expenditure distribution (i.e. the poor) save more than those at the end of the distribution (i.e. the rich). This can 
mean that the poor use the informal saving institutions as insurance schemes relative to the rich who are better positioned to access formal saving routes and other alternative schemes (Alvi and Dendir, 2009). Amount of saving increases with the number of years of schooling completed by the head. This result from the multivariate specifications is consistent with the descriptive statistics reported in Table 3. With regard to employment status, a significant positive relationship is shown when a household head is an employer or own account worker, self-employed, civil servant and private sector employee relative to an unemployed household head. Under the OLS and Heckit models, the number of female adults in the household was found to be a significant driving force affecting saving in equbs but this link did not persist under the IV estimates. Anderson and Baland (2002) obtain a similar result for urban Kenya.

Unlike the findings of Handa and Kirton (1999) for Jamaican ROSCAs, the size of $e q u b$ is not inversely related with the monthly equb contribution. The theoretical prediction, regarding the relationship between the frequencies of draw/saving and volume of saving, is not supported. Our evidence above shows that the size of equbs is modest and the duration of equbs is relatively short. This suggests that equbs mainly serve as a device for savings which is limited to intermediating local resources only. Characteristics such as the size of the pot and the size of the contribution are not flexible within a given ROSCA cycle or round. Efforts to increase the pot could be achieved by either increasing the size of the pot or the size of the contribution. Both often prove difficult during a given cycle. Members might not be able to increase their contribution. Existing members might also be reluctant to accept more members that can add to management and coordination/commitment problems and lengthen the life of the ROSCA, and 
consequently increase the time that they should wait to get their next chance of receiving the pot (Armendáriz and Morduch, 2007).

We considered a number of instruments to account for endogeneity of equb characteristics. When we used both location and occupation variables as instruments, first stage results indicate a good correlation between endogenous regressors (that is frequency of $e q u b$ and size of $e q u b$ ) and instruments. However, over identification tests led to rejection of the null of valid instruments. The same was true when we used only occupation as instruments (that is by excluding the location variables). Hence, our final results are based on using only location variables as instruments. Doing so, we found not only significant first stage correlation of the endogeneous regressors with location but also validated their usefulness empirically using the Sargan and Bartmann over-identification tests ( reported in the table below). Other studies did not instrument for size which we believe is a shortcoming. Members decide both the size of ROSCA saving and frequency of contribution meetings.

The choice of location as an instrument is based on the following intuitive justification. Different locations have different population sizes and also heterogeneous norms (attitudes) about forming ROSCAs. For instance, we anticipate finding larger ROSCAs in more densely populated locations. In addition, households in major cities have more members who are in regular public/private sector employment than households in smaller cities with semi-urban features. Hence, households in major cities appear to display a different set of norms (attitudes) when it comes to the size of ROSCA and frequency of saving (i.e. contribution) to the ROSCA funds. For instance, an employee who is normally paid monthly (more common among households in major cities than 
smaller cities) prefer to join a ROSCA which meets every four weeks or monthly. This saving frequency is, obviously, synchronised with pay day of employees and is different from the saving frequency of, for instance, a trader who earns and mobilises financial resources more frequently. In short, along with population size, location determines the occupation of individuals which in turn potentially affect their decision about the frequency of saving and the size of the saving institution they choose to join.

In interpreting the Heckit model results, note that a statistically significant $\lambda$ is evidence of the independence of the participation and saving decisions. Households make their decision of joining equbs and the amount they would like to save jointly. Identification comes by imposing the following exclusion restriction. We assume that religion and ethnic group dummies affect the propensity of joining ROSCAs or saving in informal saving schemes but not necessarily the actual amount saved once decision to join is made. The intuition for the identifying strategy or exclusion restriction is that certain ethnic and religious groups are more likely to have a propensity and awareness to participate in self-help local institutions such as ROSCAs. For instance, individuals from the Gurage ethnic group in Ethiopia often migrate from rural areas to urban centres and may rely on such institutions to raise funds. They are well known for their commercial entrepreneurship and often start from funds raised via ROSCAs. Muslims also prefer to participate more in ROSCAs than formal saving schemes such as bank deposits because they do not believe (for religious reasons) in formal saving accounts that are interest bearing. The networking effect coming from cultural variables is more important in affecting participation than the actual amount saved. In the absence of exclusion restrictions, the Heckit model is identified via a functional form. In practice, that is often guaranteed by having a sufficiently large set of explanatory variables. In 
Table 5: Determinants of Equb contribution: OLS, IV/2SLS and Heckit estimates

\begin{tabular}{llll}
\hline Variables & OLS & IV/2SLS & Heckit Model \\
\hline Constant & $11.70(10.07)$ & $7.29(40.4)$ & $12.76(10.9)$ \\
& Characteristics of the Head & \\
Log of age & $-10.04(5.23)^{*}$ & $-7.64(21.69)$ & $-12.05(5.69)^{* *}$ \\
Log of age & $1.37(0.69)^{* *}$ & $1.07(2.93)$ & $1.61(0.75)^{* *}$ \\
Years of schooling & $0.05(0.01)^{* * * *}$ & $0.04(0.38)$ & $0.06(0.01)^{* * *}$ \\
Female & $-0.11(0.15)$ & $-0.10(0.24)$ & $-0.08(0.16)$ \\
Unemployed (reference) & & & \\
Employer & $2.14(0.41)^{* * *}$ & $2.04(1.06)^{* *}$ & $2.49(0.46)^{* * *}$ \\
Self-Employed & $1.22(0.18)^{* * *}$ & $1.43(0.25)^{* * *}$ & $1.68(0.21)^{* * *}$ \\
Civil Servant & $0.48(0.19)^{* *}$ & $-0.08(1.2)$ & $0.60(0.21)^{* * *}$ \\
Private sector employee & $0.76(0.27)$ & $0.23(0.72)$ & $1.19(0.31)^{* * * *}$ \\
Pensioner & $-0.27(0.23)$ & $-0.62(0.48)$ & $-0.20(0.25)$
\end{tabular}

\section{Household characteristics}

$\begin{array}{llll}\text { Log of total expenditure } & 2.57(0.60)^{* * * *} & 2.52(1.03)^{* * *} & 2.89(0.71)^{* * * *} \\ \text { Log of total expenditure }^{2} & -0.17(0.04)^{* * *} & -0.16(0.07)^{* *} & -0.18(0.05)^{* * *}\end{array}$




$\begin{array}{llll}\text { Female Adults }>15 & 0.23(0.05)^{* * *} & 0.20(0.23) & 0.28(0.05) * * * \\ \text { Children<15 } & -0.04(0.04) & -0.05(0.10) & -0.04(0.04)\end{array}$

\section{Equb/ROSCA characteristics}

Size of ROSCA

$-0.0001(0.01)$

$-0.02(0.19)$

$-0.0004(0.004)$

Other frequency (reference)

Daily $^{a}$

$-0.28(0.48)$

$-1.93(11.6)$

$-0.17(0.43)$

Fortnightly $^{a}$

$-0.44(0.39)$

$0.94(2.43)$

$-0.38(0.37)$

Monthly $^{a}$

$-0.38(0.33)$

$0.16(3.31)$

$-0.36(0.31)$

Weekly $^{a}$

$-0.38(0.34)$

$-1.12(2.82)$

$-0.16(0.32)$

\section{Over identification tests and other diagnostics}
Sargan Test chi2 (p-value)
$0.14(0.7070)$
Basmann Test chi2(p-
0.13(0.7167)
value)
F-stat(p-value)
$9.28(0.0000)$
6.88(0.0000)
Lambda

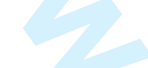
0.18
R-squared
0.39

377

\section{4}

Notes: ${ }^{a}$ Treated as exogenous in the $2^{\text {nd }}$ and $4^{\text {th }}$ columns. Standard errors are given in parentheses. $* * * ;$

** and *=significant at 1,5 and 10 percent respectively. Cultural variables such as ethnicity and religion

of the head were included in the estimation but not found to be significant.

The results show that household and household head characteristics are more important than ROSCA specific characteristics in the determination of the volume of ROSCA saving. Further robustness checks support the results (see appendix). Without the need to specify identification restrictions, we also estimated a tobit model 


\section{Conclusions and Policy Implications}

ROSCAs provide valuable services to those excluded from capital access, public assistance and insurance programmes through saving mobilisation among neighbours, friends and relatives. Based on different specifications, our robust finding is that the amount of ROSCA savings is significantly affected by the characteristics of the members but not that of the informal saving institution. For instance, individuals who live in richer households, self-employed individuals and private/international organisation employees are more likely to be ROSCA members. This indicates that financial exclusion goes beyond the mere focus on the poor; middle classes too have insufficient access to finance. This is consistent with the recent shift in the development community which calls for a broader access agenda that include middle class households and small and medium enterprise entrepreneurs (World Bank, 2008; Rajan, 2006). 
Another main finding of the paper is the high participation of women. Microfinance projects often target women (World Bank 2008) as repayment is generally higher than for men. Given that moral hazard seems to be the most constraining factor in reaching low-income households, women are generally more attractive clients due to their conservative investments and lower mobility (Emran, Morshed, and Stiglitz, 2006).

The shift in development thinking towards finance for all has built on a number of financial innovations that recognized the prevalence of informal financial institutions and their saving mobilization abilities. Ethiopian ROSCAs are restricted in size and outreach. This is common in many developing countries, which has prompted shift in development thinking towards building inclusive financial systems and improving financial access via upgrading the operations of ROSCAs and other types of informal financial institutions and integrate them into the wider financial market.

Policy makers in Sub-Saharan Africa could learn from regional and international experiences which target mainstreaming and scaling up of endogenous savings-led group-based approaches. Examples in countries such as India, Nepal, Kenya and Ghana show a number of innovative networking initiatives that entail linkages with commercial banks, enhancing management and operations capabilities and transformation of rotating and non rotating savings and credit associations into financial intermediaries with permanent funds (Seibel 2001; Takahashi, 2009; Awusabo-Asare et al, 2009).

Without huge budgetary responsibilities, Ethiopian ROSCAs can be supported to enhance their sustainability and outreach. This would enhance the investment role of 
ROSCAs given the poor performance of the formal sector to provide saving and investment possibilities for excluded groups such as the poor and the self-employed. The gradual transformation of Ethiopian ROSCAs might entail registering them (particularly the larger ones) as cooperatives as these institutions do not currently have a profit motive. Such a move can provide legal protection against potential problems such as defaulting which can be the case more in urban than rural areas. Other advantages include efficient saving collection, computerisation of financial records, expansion of membership and consequently bringing in larger working capital for participants. In countries where the law does not allow it, governments need to pass an act that makes the transformation possible as in the case of Nepal (Seibel and Shrader, 1999). We believe this is a feasible policy to follow in Ethiopia and others parts of Africa. However, such a transformation very much depends on recognising the heterogeneous cultural, legal and socio-economic situation of each country. Our econometric results give a good guide on whom to target for support. In the participation equation, the self-employed are more likely to save in ROSCAs and the contribution equation shows that those who are at the lower end of the household expenditure distribution save move. Therefore, the poor and the self-employed can benefit more from the transformation of ROSCAs and this ties in well with overall objective of economic development.

With gradual transformation, ROSCAs participants can use funds for small investment projects (e.g. setting up small businesses such as vending) instead of consumption expenditure. Eventually, this leads to sustainable self-sufficiency and address some of the chronic lack of employment and other livelihood opportunities. This is important for many urban centres in the developing world where there are no convenient saving 
deposit facilities. As indigenous sources of working capital, saving mobilisation via ROSCAs should not be neglected in favour of the formal financial sector which already failed to serve the majority of urban dwellers in Sub-Saharan Africa.

ROSCAS can put locally held funds to good use and help credit constrained individuals to purchase indivisible goods. However, they might not act as an effective way to move resources across independent communities or to expand in size. The institutional characteristics such as size of the contribution are not flexible within the life time of a given ROSCA. Therefore, the relevance of ROSCA as a consumption or investment finance vehicle should not be overstated. Our evidence suggests that the characteristics of the participating individuals should be given more policy attention. Policy should focus on supporting households to increase saving levels, set up businesses and employment generation. This has economy wide benefits beyond improving the welfare of households and their communities.

This study shows the importance of the Ethiopian ROSCA (equb) as a key informal saving institution in urban areas. We demonstrate that the size of equb contribution is significantly influenced by household and household head characteristics but not by $e q u b$ specific characteristics. This is a robust finding which highlights the importance of a careful consideration of the existing theoretical literature linking equb contribution solely to the characteristics of the saving institution without due attention to the characteristics of the members of the institution. It is true that ROSCA characteristics can be important in determining the size of saving, as in Jamaica. However, their importance in other settings might be negligible, as in urban Ethiopia relative to the characteristics of participants. The findings suggest the need for tests on data from 
more developing countries (and these should not ignore the endogeneity of the size of ROSCAs). Furthermore, more policy focus should be directed at the characteristics of the ROSCA participants to improve the saving position of households and hence economic growth.

In an era of disappointment with formal financial institutions, policies can be designed to help vulnerable societal members (e.g. women) and to target poor households for credit initiatives that support them to set up self-help businesses. This will lead to economy wide employment creation, facilitate growth and improve living standards. The reasons to join ROSCAs highlight the important role played by informal financial institution in economic development. Equbs in Ethiopia allow households to benefit from inter-temporal trade resulting in better capital accumulation. This has significant implication in terms of drawing the attention of policy makers in Ethiopia and elsewhere in the developing world to the productive role played by such an informal institutional settings where the formal sector is very weak or absent in terms of resource mobilisation.

\section{References}

Alvi, E. and Dendir, S. (2009) Private Transfers, Informal Loans and Risk Sharing Among Poor Urban Households in Ethiopia. Journal of Development Studies, 45 (8), pp.1325-1343. 
Ambec, S and Treich, N. (2007) ROSCAs as financial agreements to cope with selfcontrol problems. Journal of Development Economics, 82 (1), pp 120-37.

Anderson, S. and Baland, J.M. (2002) The Economics of ROSCAs and Intrahousehold Resource Allocation. Quarterly Journal of Economics, 117(3), pp. 962-995.

Ardener, S. and Burman, S (1995) Money-Go-Rounds: The Importance of Rotating Savings and Credit Associations for Women. BERG, Oxford/Washington D.C., USA.

Aredo, D. (1993) The informal and semi-formal sectors in Ethiopia; a Study of the iqqub, iddir, savings and credit cooperatives. AERC research paper, African Economic Research Consortium, Nairobi, Kenya.

Awusabo-Asare, K., Annim, S., Abane, A. and Asare-Minta, D (2009). Who is Reaching Whom? Depth of Outreach of Rural Micro Finance Institutions in Ghana. International NGO Journal, 4 (4), pp. 132-141.

Begashaw, G. (1978) The Role of Traditional Savings and Credit Institutions in Ethiopia. Savings and Development 2, pp. 249-262.

Besley, T. (1995) Nonmarket Institutions for Credit and Risk Sharing in Low-Income Countries. Journal of Economic Perspectives 9 (3), pp.115-127.

(1994) How do Market Failures Justify Interventions in Rural Credit Markets. World Bank Research Observer 9 (1), pp. 27-47. 
Besley, T. and Levenson, A. R. (1996) The Role of Informal Finance in Household Capital Accumulation: Evidence from Taiwan. The Economic Journal, 106 (January 434), pp. 39-59.

Besley, T., S. Coate and Loury, G. (1993) The Economics of Rotating Savings and Credit Associations. The American Economic Review, 83 (4), pp. 792-810.

Bonnet, A. (1981) Institutional Adaptation of West Indian Immigrants to America: An Analysis of Rotating Credit Associations (Washington D.C.: University press of America).

Bouman, F. J. A (1995) Rotating and Accumulating Savings and Credit Associations: A Development Perspective. World Development, 23 (3), pp. 371-384.

Calomiris, C. and Rajaraman, I. (1998) The Role of ROSCAs: Lumpy Durables or Event Insurance? Journal of Development Economics, 56 (1), pp. 207-216.

Callier, P. (1990) Informal Finance: The Rotatings Savings and Credit Association- an Interpretation. Kyklos, 43 (2), pp. 273-276.

Carpenter, S. B. and Jensen, R. T. (2002) Household Participation in Formal and Informal Savings Mechanisms: Evidence from Pakistan. Review of Development Economics, 6 (3), pp. 314-328. 
Cox, D. and E. Jimenez (1998) Risk Sharing and Private Transfers: What About Urban Households? Economic Development and Cultural Change, 46 (3), pp.621-637.

Dagnelie, O. and LeMay-Boucher, P. (2009) ROSCA Participation in Benin: a Commitment Issue. Working paper, Department of Economics, School of Management and Languages, Heriot-Watt University, Edinburgh.

Diagne, A. and Zeller, M. (2001) Access to Credit and its Impact on Welfare in Malawi. Research Report 116, IFPRI, Washington, D.C.

Emran, M. S., Morshed, A.M., and Stiglitz, J.E (2007). Microfinance and Missing Markets. Working Paper, George Washington University.

Etang, A., Fielding, D. and Knowles, S. (2007) Survey Trust, Experimental Trust and ROSCA membership in Rural Cameroon. Discussion Paper 0713, University of Otago, New Zealand.

Gebremedhin, T. and Whelan, S. (2008) Prices and Poverty in Urban Ethiopia. Journal of African Economies, 17 (1), pp. 1-33.

Gugerty, M.K. (2007) You can't Save Alone: Commitment and Rotating Savings and Credit Associations in Kenya. Economic Development and Cultural Change, 5 (2), pp. 251-82. 
Handa, S. and C. Kirton (1999) The Economics of Rotating Savings and Credit Associations: evidence from the Jamaican 'Partner'. Journal of Development Economics, 60 (1), pp. 173-194.

Hoddinott, J., Dercon, S.and Krishnan, P. (2005) Networks and Informal Mutual Support, in 15 Ethiopian Villages. Mimeo, University of Oxford, UK.

Honohan P and Beck, T. (2007) Making Finance Work for Africa. World Bank, Washington DC.

Ibrahim, G., and Galt, V. (2003) Ethnic Business Development: Toward a Theoretical Synthesis and Policy Framework. Journal of Economic Issues, 37 (4), pp. 1107-119.

Kedir, A., Ibrahim, G. and S. Torres (2010) Household Level Credit Constraints in Urban Ethiopia. Mimeo, University of Leicester, UK.

Kimuyu, P. (1999) Rotating Saving and Credit Associations in Rural East Africa. World Development, 27 (7): 1299-1308.

Klonner, S. (2003) Rotating Savings and Credit Associations with Risk Averse Participants. International Economic Review, 44 (3), pp. 979-1005.

Levenson, A. R., and Besley, T. (1996) The Anatomy of an Informal Financial Market: ROSCA participation in Taiwan. Journal of Development Economics, 51 (1), pp.4568. 
Platteau, J.P. (2000) Institutions, Social Norms and Economic Development. Harwood Academic Publisher, USA.

\author{
Rajan, R. M., (2006) Has finance made the world riskier? European Financial \\ Management, 12 (4), pp 499-533.
}
Seibel, H. D. and Schrader, H. (1999) From Informal to Formal Finance: The Transformation of an Indigenous Institution in Nepal. Mimeo, Development Research Centre, University of Cologne.

Seibel, H.D (2001). Mainstreaming Informal Financial Institutions. Journal of Developmental Entrepreneurship, 6 (1), pp 83-95.

Srinivasan, S. (1995) ROSCAs among South Asians in Oxford, in Shirley Ardener and Sandra Burman (eds) Money-go-rounds: The Importance of Rotating Savings and Credit Associations for Women, (Washington DC: BERG), pp. 199-208.

Takahashi, L.M (2009). Evolving Institutional Arrangements, Scaling Up, and Sustainability: Emerging Issues in Participatory Slum Upgrading in Ahmadabad, India. Journal of Planning Education and Research, 29 (2), pp. 213-232

UNCTAD (2007) Economic Development in Africa: Reclaiming Policy Space, Domestic Resource Mobilization and Developmental States, New York and Geneva, UNCTAD 
Appendix Table A1

Determinants of ROSCA contribution: Tobit estimates

World Bank (2008) Finance for All? Policies and Pitfalls in Expanding Access. The World Bank Washington D.C.

\section{Coefficient(std error)}

\section{Variables}

$-1577.7(0.44)$

Constant

$403.79(0.22)$

Log of age 2

Years of schooling

$1.75(0.35)$

Female

$-5.75(0.10)$

\section{Unemployed (reference)}

Employer

$612.14(4.25)^{* * *}$

Self-Employed

$272.46(4.20) * * *$

Civil Servant

$30.62(0.44)^{* *}$

Private sector employee

$96.99(1.02)$

Pensioner

$-103.92(1.26)$ 
Household characteristics

Log of total expenditure

217.57(1.01)

Log of total expenditure^ 2

$-8.95(0.58)$

Female Adults $>15$

$91.00(5.44)^{* * * *}$

Children $<15$

$-12.31(0.94)$

\section{Equb/ROSCA characteristics}

Size of ROSCA

$0.46(0.21)$

Other frequency (reference category)

Daily

Fortnightly

$0.60(0.43)$

Monthly

$0.41(0.35)$

Weekly

195.7(1.51)

other diagnostics

LR chi2(p-value) $\quad 121.10$

Sigma

$397.49(14.48)$

R-squared

0.39

\section{No of observations}

1414

Notes: T-ratios are given in parentheses. ${ }^{* * *} ; * *$ and $*=$ significant at 1,5 and 10 percent respectively. Total household expenditure was found to be statistically significant when entered without the quadratic term testifying to the important of household welfare position for ROSCA contribution. However, the ROSCA characteristics were found to be still statistically insignificant. 